\title{
Proceeding
}

8th INSHS International Christmas Sport Scientific Conference, 5-7 December 2013. International Network of Sport and Health

Science. Szombathely, Hungary

\section{Strength training and changes in the dynamics of running economy}

\author{
JAN CACEK $\triangle$, KALINA TOMÁŠ, DOLEŽAL MARTIN \\ Faculty of Sport Studies, Masaryk University Brno, Czech Republic
}

\begin{abstract}
Cacek, J., Tomáš, K. \& Martin, D. (2014). Strength training and changes in the dynamics of running economy. J. Hum. Sport Exerc., 9(Proc 1), pp.S467-S473. The aim of this study was to examine an acute effect of 4RM training and plyometric training (PT) on running economy (RE; $\mathrm{O}_{2}$ consumption) in endurance runners during a 48 hour interval. Eight performance runners (age 25.4 \pm 1.4 years) completed a maximum strength training (4RM) of lower limbs ( 3 sets, rest $2 \mathrm{~min}, 5$ exercises) and subsequently underwent a RE test on a treadmill (speed 8,10 and $\left.12 \mathrm{~km} \cdot \mathrm{h}^{-1}\right)$ at three time intervals $(0,+24$ and $+48 \mathrm{~h}$ ) after the training. We found that the average $\mathrm{VO}_{2} \cdot \mathrm{BM}^{-1} \cdot \mathrm{min}^{-1}$ and $\Delta \mathrm{VO}_{2} \cdot \mathrm{BM}^{-1} \cdot \mathrm{min}^{-1}$ at the given speed increased from baseline (a pretest $48 \mathrm{~h}$ before the strength intervention) by 2.3-5.6\% and culminated after $24 \mathrm{~h}$. These changes in RE after the strength intervention were not statistically significant, when compared to the pretest (48 $\mathrm{h}$ before the intervention). The second investigation was conducted in seven runners (age $25 \pm 1.6$ years). This time the intervention was plyometric ( $7 \mathrm{sec}$ load, rest 2 min, maximum intensity, 3 sets, 6 exercises on the dominant lower limb). We found that the average $\mathrm{VO}_{2} \cdot \mathrm{BM}^{-1} \cdot \mathrm{min}^{-1}$ and $\Delta \mathrm{VO}_{2} \cdot \mathrm{BM}^{-1} \cdot \mathrm{min}^{-1}$ at given speeds at intervals $0,+24$ and $+48 \mathrm{~h}$ did not increase, when compared to the pretest $(\mathrm{p}<0.05$; $\max$ $+1 \%$ ). These minimal changes probably resulted from the design of the PT, which had not a sufficiently destructive effect on muscle cells. The comparison of these two investigations indicates a stronger (although statistically insignificant) deterioration of RE after 4RM training versus PT. Key words: OXYGEN UPTAKE, ACUTE EFFECT, PLYOMETRIC, MAXIMUM POWER.
\end{abstract}

Corresponding author. Faculty of Sport Studies, Masaryk University Brno, Czech Republic.

E-mail: cacek@fsps.muni.cz

8th INSHS International Christmas Sport Scientific Conference, 5-7 December 2013. International Network of Sport and Health Science. Szombathely, Hungary.

JOURNAL OF HUMAN SPORT \& EXERCISE ISSN 1988-5202

(c) Faculty of Education. University of Alicante

doi:10.14198/jhse.2014.9.Proc1.34 


\section{INTRODUCTION}

Running economy (RE) is regarded as a physiological criterion of running efficiency. RE is defined as the consumption of $\mathrm{O}_{2}$ required for an exercise activity of an endurance character (Conley et al., 1981; Morgan et al., 1989). In running events, it is expressed as a consumption of $\mathrm{O}_{2}$ per body weight per one minute of running at the selected speed $\left(\mathrm{ml}^{\mathrm{kg}} \mathrm{kg}^{-1} \cdot \mathrm{min}^{-1}\right)$.

\section{Intervention programmes and $R E$}

The impact of several weeks' plyometric intervention programs on changes in running economy (RE) was investigated in many studies in the past (Foster \& Lucia, 2007; Spurrs et al., 2003; Turner et al., 2003). The results of these studies indicate that plyometric training has a positive effect on the development of RE. According to Spurrs et al. (2003), systematically applied plyometric training affects muscle-tendon tension in some parts of lower limbs, which lowers oxygen consumption when running at the same running speed during a pretest and a posttest.

Similarly like plyometric programs, even maximum-strength intervention programs can positively influence indicators of RE. Evidence for such a statement can be found in studies of Storen et al. (2008) and Hoffa et al. (2002), whose results show positive effects of a maximum strength training on RE in trained athletes.

Acute effects of strength and plyometric training on RE

The immediate effect of a maximum strength or plyometric training on indicators of $R E$ is not described in the available literature. Thus, the question remains, what specific practices influence RE. The research of delayed muscle sensitivity after plyometric training (Marginson et al., Twist et al., In: Kampmiller et Vanderka, 2006) suggests that delayed muscle sensitivity culminates after about 48 hours and is accompanied by a performance decrease and an increase of the levels of creatine kinase. At the same time, the levels of creatine kinase and other indicators of muscle damage depend on the intensity and volume of the realized load, the fitness of the tested athletes, regenerative treatments, etc.

The aim of this study was to examine an acute effect of 4RM training and plyometric training (PT) on running economy ( $\mathrm{RE} ; \mathrm{O}_{2}$ consumption) in endurance runners during a 48 hour interval.

\section{MATERIAL AND METHODS}

\section{Participants}

Two groups of middle distance runners, who participated in this study, had been selected among the students of the Faculty of Sports Studies at the Masaryk University in Brno. The main selection criterion was a regular athletic training at least 4 times a week, for at least three years, and a performance in the 1,500 $\mathrm{m}$ under 4:20 (at the time of this study's realization). All runners participated in the study voluntarily.

The first group included 8 performance runners (age $25.4 \pm 1.4$ years) undergoing maximum strength training. The second group consisted of 7 runners (age $25 \pm 1.6$ years) undergoing a plyometric intervention.

Procedures

At first, the tested groups underwent an entrance test of running economy (RE). After 48 hours since the entrance test, they went through a maximum strength intervention (the intensity of 4RM; hereinafter referred to as 4RM) or a plyometric intervention, followed by a measurement of RE indicators at three time 
intervals: immediately after the strength or plyometric training (day 0), 24 hours (day 1) and 48 hours (day 2) after the strength or plyometric training.

The test of RE was performed on a treadmill (Catana, Lode, Netherlands), always with 3 pre-set speeds (8, 10 and $12 \mathrm{~km} \cdot \mathrm{h}^{-1}$ ), so that the highest speed was below the anaerobic threshold. The length of the interval at each pre-set speed was 5 minutes and the test had a continuous character, with no rest between intervals. The monitored parameters were $\mathrm{VO}_{2} \cdot \mathrm{BM}^{-1} \bullet \mathrm{min}^{-1}$ and $\Delta \mathrm{VO}_{2} \cdot \mathrm{BM}^{-1} \bullet \mathrm{min}^{-1}$. The recording of $\mathrm{VO}_{2}$ was performed during the last 2 minutes of the load (as the average of $10 \mathrm{sec}$. records) using the apparatus Metalyzer 3b (Cortex Biophysik $\mathrm{GmbH}$, Germany), the breath-by-breath method.

The maximal strength training included 5 exercises implemented in three sets with a 2-minute passive rest interval. The intensity of exercises was set at 4RM. The exercises consisted of: Leg-press, leg flexion on a machine, leg extension on a machine, calf raises on the Multipress, forward lunges with dumbbells.

The plyometric training was designed as a $7 \mathrm{sec}$. load of maximum intensity (with ATP-CP as the dominant energy source) with 2 minutes of rest between sets and exercises. The training included three sets of these 6 exercises: Squat $\left(90^{\circ}\right)$ jumps, jumping lunge, explosive push-ups, ankle jumps, side to side jumps, jumps off a bench and vertical jumps.

The testing of RE was performed at a constant temperature of $20 \pm 1^{\circ} \mathrm{C}$. The tested subjects underwent all $\mathrm{RE}$ measurements in the same shoes and the same clothes. Two days before the entrance test and during the execution of the research, the test subjects had a regime without any sports activity. Before each measurement, we calibrated the $3 \mathrm{~b}$ metalyzer using a calibration cylinder ( 3 Liter Calibration Syringe, Cortex, Germany).

\section{Analysis}

Data were expressed as $\Delta \mathrm{VO}_{2} \cdot \mathrm{BM}^{-1} \cdot \mathrm{min}^{-1}$. Data analysis was performed using pretest to posttest changes $(0 \mathrm{~h}, 24 \mathrm{~h}, 48 \mathrm{~h})$, assessed by Tukey HSD test for paired samples. The level of $p<0.05$ was considered as statistically significant. The software program Statistica 12 was used for all statistical analyses. Considering that we compared results of two independent tests with the same design, but a different type of training, we used a relative expression of changes in $\mathrm{RE}(\%)$.

\section{RESULTS}

Table 1. Descriptive Statistics for RE (4RM training)

\begin{tabular}{|c|c|c|c|c|c|c|c|c|}
\hline \multirow[b]{2}{*}{ Effect } & \multicolumn{8}{|c|}{ Descriptive Statistics (RE) - Exclude condition: v1=-1 } \\
\hline & $\begin{array}{l}\text { Level of } \\
\text { (Factor) }\end{array}$ & $\begin{array}{l}\text { Level of } \\
\text { (Factor) }\end{array}$ & $\mathrm{N}$ & $\begin{array}{c}\text { deltaVO } \\
\text { (Mean) }\end{array}$ & $\begin{array}{c}\text { deltaVO } \\
\text { (Std.Dev.) }\end{array}$ & $\begin{array}{l}\text { deltaVO } \\
\text { (Std.Err) }\end{array}$ & $\begin{array}{c}\text { deltaVO } \\
95,00 \%)\end{array}$ & $\begin{array}{r}\text { deltaVO } \\
(+95,00 \%)\end{array}$ \\
\hline day ${ }^{*}$ velocity & 0 & 8 & 8 & 1.025920 & 0.102836 & 0.036358 & 0.939947 & 1.111893 \\
\hline day*velocity & 0 & 10 & 8 & 1.030166 & 0.102166 & 0.036121 & 0.944753 & 1.115579 \\
\hline day $^{*}$ velocity & 0 & 12 & 8 & 1.033781 & 0.081266 & 0.028732 & 0.965841 & 1.101721 \\
\hline day $^{*}$ velocity & 1 & 8 & 8 & 1.035602 & 0.078804 & 0.027861 & 0.969720 & 1.101483 \\
\hline day $^{*}$ velocity & 1 & 10 & 8 & 1.022941 & 0.071716 & 0.025356 & 0.962985 & 1.082897 \\
\hline day $^{*}$ velocity & 1 & 12 & 8 & 1.055692 & 0.060260 & 0.021305 & 1.005314 & 1.106070 \\
\hline day $^{*}$ velocity & 2 & 8 & 8 & 1.017152 & 0.058039 & 0.020520 & 0.968630 & 1.065674 \\
\hline day*velocity & 2 & 10 & 8 & 1.030669 & 0.064250 & 0.022716 & 0.976954 & 1.084383 \\
\hline day*velocity & 2 & 12 & 8 & 1.040666 & 0.039006 & 0.013791 & 1.008056 & 1.073276 \\
\hline
\end{tabular}


Table 2. Tukey HSD test (4RM training)

\begin{tabular}{|c|c|c|c|c|c|c|c|c|c|c|c|}
\hline \multirow[t]{2}{*}{ Cell No. } & \multicolumn{11}{|c|}{$\begin{array}{c}\text { Tukey HSD test; variable deltaVO2 (RE) } \\
\text { Approximate Probabilities for Post Hoc Tests } \\
\text { Error: Between MS }=, 00574, \mathrm{df}=63,000 \\
\text { Exclude condition: } \mathrm{v} 1=-1\end{array}$} \\
\hline & day & velocity & $\begin{array}{c}\{1\} \\
(1,0259)\end{array}$ & $\begin{array}{c}\{2\} \\
(1,0302)\end{array}$ & $\begin{array}{c}\{3\} \\
(1,0338)\end{array}$ & $\begin{array}{c}\{4\} \\
(1,0356)\end{array}$ & $\begin{array}{c}\{5\} \\
(1,0229)\end{array}$ & $\begin{array}{c}\{6\} \\
(1,0557)\end{array}$ & $\begin{array}{c}\{7\} \\
(1,0172)\end{array}$ & $\begin{array}{c}\{8\} \\
(1,0307)\end{array}$ & $\begin{array}{c}\{9\} \\
(1,0407)\end{array}$ \\
\hline 1 & 0 & 8 & & 1.000000 & 1.000000 & 0.999999 & 1.000000 & 0.996932 & 1.000000 & 1.000000 & 0.999984 \\
\hline 2 & 0 & 10 & 1.000000 & & 1.000000 & 1.000000 & 1.000000 & 0.998988 & 0.999994 & 1.000000 & 0.999999 \\
\hline 3 & 0 & 12 & 1.000000 & 1.000000 & & 1.000000 & 0.999999 & 0.999678 & 0.999960 & 1.000000 & 1.000000 \\
\hline 4 & 1 & 8 & 0.999999 & 1.000000 & 1.000000 & & 0.999995 & 0.999831 & 0.999911 & 1.000000 & 1.000000 \\
\hline 5 & 1 & 10 & 1.000000 & 1.000000 & 0.999999 & 0.999995 & & 0.994075 & 1.000000 & 1.000000 & 0.999934 \\
\hline 6 & 1 & 12 & 0.996932 & 0.998988 & 0.999678 & 0.999831 & 0.994075 & & 0.982791 & 0.999124 & 0.999981 \\
\hline 7 & 2 & 8 & 1.000000 & 0.999994 & 0.999960 & 0.999911 & 1.000000 & 0.982791 & & 0.999992 & 0.999458 \\
\hline 8 & 2 & 10 & 1.000000 & 1.000000 & 1.000000 & 1.000000 & 1.000000 & 0.999124 & 0.999992 & & 0.999999 \\
\hline 9 & 2 & 12 & 0.999984 & 0.999999 & 1.000000 & 1.000000 & 0.999934 & 0.999981 & 0.999458 & 0.999999 & \\
\hline
\end{tabular}

day*velocity; Unweighted Means

Current effect: $F(4,63)=, 11122, p=, 97815$

Effective hypothesis decomposition

Vertical bars denote 0,95 confidence intervals

Exclude condition: $\mathrm{v} 1=-1$

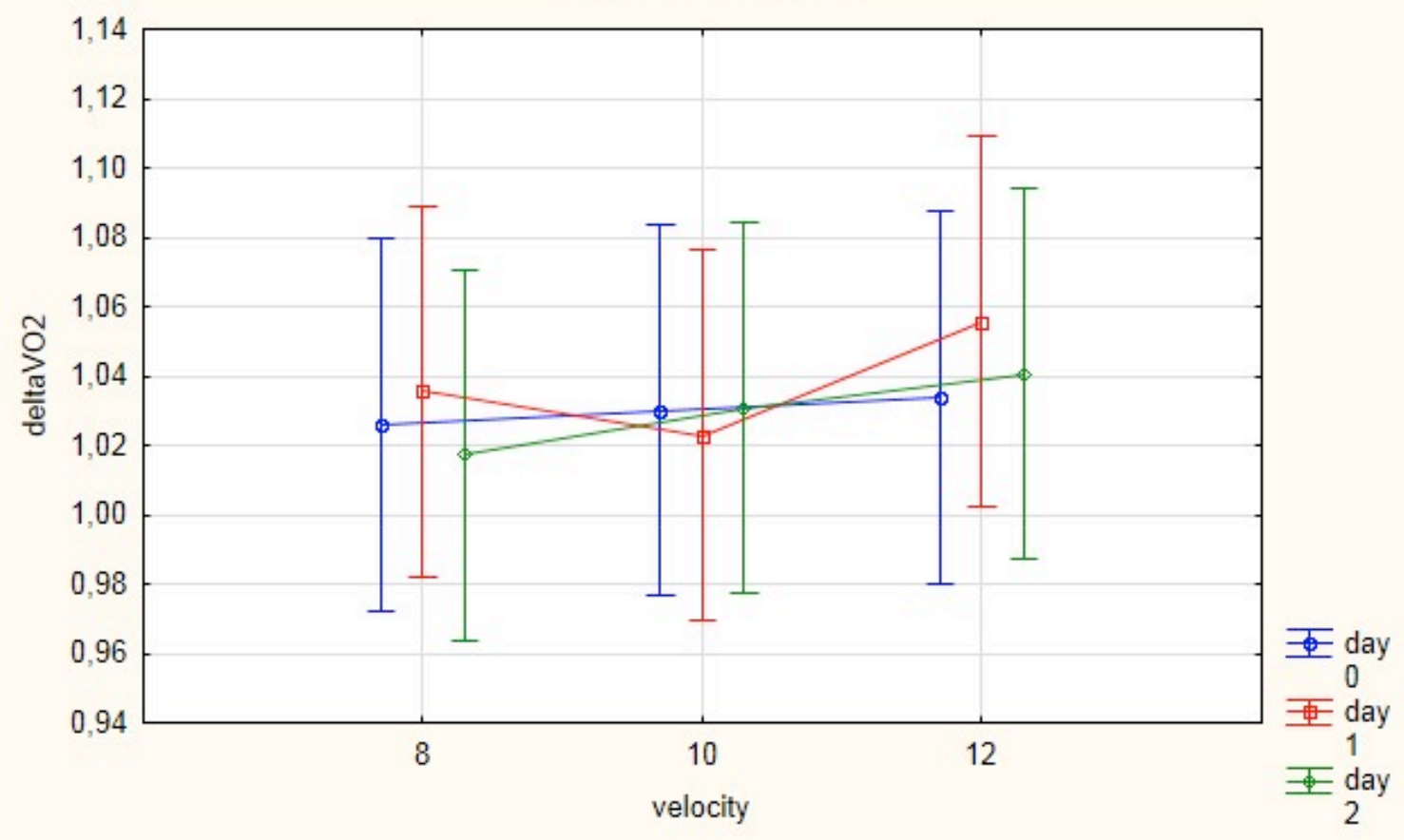

Figure 1. Differences in running economy (4RM training) 
Table 3. Tukey HSD test (Plyometric training)

\begin{tabular}{|c|c|c|c|c|c|c|c|c|}
\hline \multirow[b]{2}{*}{ Effect } & \multicolumn{8}{|c|}{ Descriptive Statistics (RE) - Exclude condition: v3=-1 } \\
\hline & $\begin{array}{l}\text { Level of } \\
\text { (Factor) }\end{array}$ & $\begin{array}{l}\text { Level of } \\
\text { (Factor) }\end{array}$ & $\mathrm{N}$ & $\begin{array}{c}\text { deltaVO}_{2} \\
\text { (Mean) }\end{array}$ & $\begin{array}{c}\text { deltaVO } \\
\text { (Std.Dev.) }\end{array}$ & $\begin{array}{l}\text { deltaVO }_{2} \\
\text { (Std.Err) }\end{array}$ & $\begin{array}{c}\text { deltaVO }(- \\
95,00 \%)\end{array}$ & $\begin{array}{c}\text { deltaVO } \\
(+95,00 \%)\end{array}$ \\
\hline day*velocity & 0 & 8 & 7 & 0.991058 & 0.041640 & 0.015738 & 0.952547 & 1.029568 \\
\hline day*velocity & 0 & 10 & 7 & 1.018327 & 0.037936 & 0.014338 & 0.983242 & 1.053411 \\
\hline day*velocity & 0 & 12 & 7 & 0.995963 & 0.041059 & 0.015519 & 0.957990 & 1.033936 \\
\hline day*velocity & 1 & 8 & 7 & 0.991740 & 0.040685 & 0.015377 & 0.954113 & 1.029368 \\
\hline day*velocity & 1 & 10 & 7 & 0.989821 & 0.057661 & 0.021794 & 0.936494 & 1.043149 \\
\hline day*velocity & 1 & 12 & 7 & 0.995408 & 0.044464 & 0.016806 & 0.954286 & 1.036530 \\
\hline day*velocity & 2 & 8 & 7 & 0.991162 & 0.026437 & 0.009992 & 0.966712 & 1.015612 \\
\hline day*velocity & 2 & 10 & 7 & 1.002193 & 0.045462 & 0.017183 & 0.960148 & 1.044239 \\
\hline day*velocity & 2 & 12 & 7 & 0.998244 & 0.031600 & 0.011944 & 0.969019 & 1.027469 \\
\hline
\end{tabular}

We found that in the sample that had performed the $4 \mathrm{RM}$ training, $\Delta \mathrm{VO}_{2} \cdot \mathrm{BM}^{-1} \bullet \mathrm{min}^{-1} \mathrm{grew}$ by ca. $+1.7-5.6 \%$ at 8,10 and $12 \mathrm{~km} \cdot \mathrm{h}-1^{-1}$ and all time intervals $(0,1,2)$, when compared to the pretest (48 $\mathrm{h}$ before the $4 \mathrm{RM}$ intervention), and culminated after 24 hours, with the exception of $10 \mathrm{~km} \cdot \mathrm{h}^{-1}$ (Table 1).

The biggest differences in running economy were observed at the speed of $12 \mathrm{~km} \cdot \mathrm{h}^{-1}$, during all measured intervals (Figure 1). In contrast, the smallest differences were found at the lowest speed (except interval 1). In general, the results show that running economy deteriorated in comparison with the pretest. However, the observed changes were not significant at $p<0.05$ (Table 2).

The plyometric training (performed during the interval 0 ) did not lead to a significant deterioration of $R E(p<$ 0.05 ), neither at the tested speeds, nor during the monitored intervals $(0,1,2)$ (see Table 3 ). To the contrary, we found that the average $\Delta \mathrm{VO}_{2} \cdot \mathrm{BM}^{-1} \cdot \mathrm{min}^{-1}$ at given speeds showed signs of a slight decrease (up to $-1 \%$ ), at all time intervals. Only at the speed of $10 \mathrm{~km} \cdot \mathrm{h}^{-1}$ and time intervals 0 and 2, we observed a slight deterioration of $\mathrm{RE}\left(=\mathrm{VO}_{2}\right.$ increased) by +1.8 and $0.2 \%$, respectively (Table 4 ).

Table 4. Descriptive Statistics for RE (Plyometric training)

\begin{tabular}{|c|c|c|c|c|c|c|c|c|c|c|c|}
\hline \multirow[b]{2}{*}{ Cell No. } & \multicolumn{11}{|c|}{$\begin{array}{c}\text { Tukey HSD test; variable deltaVO } 2 \text { (RE) } \\
\text { Approximate Probabilities for Post } \mathrm{Hoc} \text { Tests } \\
\text { Error: Between } \mathrm{MS}=, 00173, \mathrm{df}=54,000 \\
\text { Exclude condition: } \mathrm{v} 3=-1\end{array}$} \\
\hline & day & velocity & $\begin{array}{c}\{1\} \\
(, 99106)\end{array}$ & $\begin{array}{c}\{2\} \\
(1,0183) \\
\end{array}$ & $\begin{array}{c}\{3\} \\
(, 99596)\end{array}$ & $\begin{array}{c}\{4\} \\
(, 99174)\end{array}$ & $\begin{array}{c}\{5\} \\
(, 98982)\end{array}$ & $\begin{array}{c}\{6\} \\
(, 99541)\end{array}$ & $\begin{array}{c}\{7\} \\
(, 99116) \\
\end{array}$ & $\begin{array}{c}\{8\} \\
(1,0022) \\
\end{array}$ & $\begin{array}{c}\{9\} \\
(, 99824)\end{array}$ \\
\hline 1 & 0 & 8 & & 0.947049 & 1.000000 & 1.000000 & 1.000000 & 1.000000 & 1.000000 & 0.999887 & 0.999996 \\
\hline 2 & 0 & 10 & 0.947049 & & 0.983801 & 0.954116 & 0.932420 & 0.981108 & 0.948177 & 0.998237 & 0.991933 \\
\hline 3 & 0 & 12 & 1.000000 & 0.983801 & & 1.000000 & 0.999999 & 1.000000 & 1.000000 & 0.999999 & 1.000000 \\
\hline 4 & 1 & 8 & 1.000000 & 0.954116 & 1.000000 & & 1.000000 & 1.000000 & 1.000000 & 0.999930 & 0.999998 \\
\hline 5 & 1 & 10 & 1.000000 & 0.932420 & 0.999999 & 1.000000 & & 0.999999 & 1.000000 & 0.999752 & 0.999987 \\
\hline 6 & 1 & 12 & 1.000000 & 0.981108 & 1.000000 & 1.000000 & 0.999999 & & 1.000000 & 0.999998 & 1.000000 \\
\hline 7 & 2 & 8 & 1.000000 & 0.948177 & 1.000000 & 1.000000 & 1.000000 & 1.000000 & & 0.999895 & 0.999997 \\
\hline 8 & 2 & 10 & 0.999887 & 0.998237 & 0.999999 & 0.999930 & 0.999752 & 0.999998 & 0.999895 & & 1.000000 \\
\hline 9 & 2 & 12 & 0.999996 & 0.991933 & 1.000000 & 0.999998 & 0.999987 & 1.000000 & 0.999997 & 1.000000 & \\
\hline
\end{tabular}




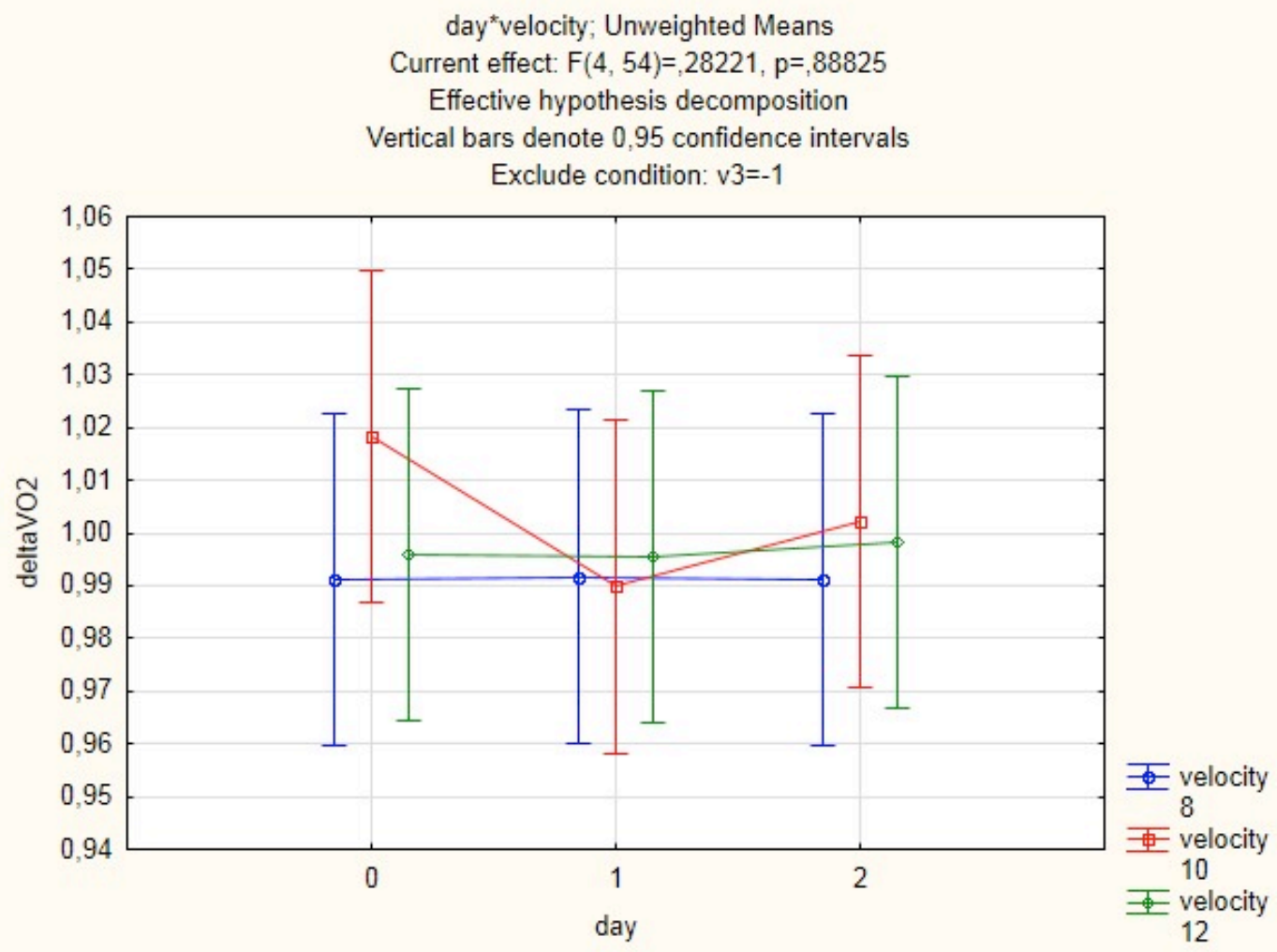

Figure 2. Differences in running economy (Plyometric training)

Mean differences in $\Delta \mathrm{VO}_{2} \cdot \mathrm{BM}^{-1} \bullet \mathrm{min}^{-1}$ (at all speeds and during all monitored intervals) were greater after the application of the 4RM training than after the application of the plyometric training (Figure 1 and 2).

\section{DISCUSSION}

The results of our study indicate that changes of RE after the application of a 4RM training and a plyometric training are insignificant. These minimal changes probably result from the design of used interventions that may not have had a destructive impact on the involved muscle cells. As already noted in the introduction (according to Marginson et al., Twist et al, In: Kampmiller \& Vanderka, 2006), the culmination of the delayed muscle sensitivity was observed after ca. 48 hours. The degree of muscle damage depends on the used load (its volume and intensity, the fitness of tested athletes, etc.), which could influence overall results and minor changes of RE. It would be interesting and desirable to repeat the research with corrections of the training design, especially with respect to the volume of work performed within a training session.

It is interesting to note that the greatest recorded means of $\Delta \mathrm{VO}_{2} \cdot \mathrm{BM}^{-1} \mathrm{~min}^{-1}$ were observed at the highest speeds $\left(12 \mathrm{~km}^{\circ} \mathrm{h}^{-1}\right)$. The question is, whether the changes in RE (worsening) after the interventions were not greater if we performed RE measurements at speeds around the anaerobic threshold, or at specific competition speeds. 


\section{CONCLUSIONS}

The comparison of the immediate effect of two different interventions showed that the design of the 4RM training caused a greater (but not significant) deterioration of $\mathrm{RE}$, when compared to the design of the plyometric training.

The results of this study can be used for the praxis of the planning and management of sports training. It can be expected that after the application of our proposed designs of the 4RM strength and plyometric trainings, there will be no fundamental changes in RE and no decline of performance at low speeds during subsequent low-intensity, short-term endurance loads (within the following 48 hours).

\section{SOURCE OF FUNDING FOR THE STUDY}

This investigation was conducted within the framework of a specific students' research at the Masaryk University 0790/2012 "Factors affecting the economy of running (the effect of explosive strength training and stretching acutely applied before performance on the economy of running) II".

\section{REFERENCES}

1. Conley, D., Krahenbuhl, G. \&, Burkett, L. (1981). Training for aerobic capacity and running economy. Physical Sportsmen, 9, pp.107-115.

2. Foster, C. \& Lucia, A. (2007) Running economy: the forgcitten factor in elite performance. Sports Med, 37, pp.316-319.

3. Hoff, J., Gran, A. \& Helgerud, J. (2002). Maximal strength training improves aerobic endurance performance. In: Scand J Med Sci Sports, 12, pp.288-295.

4. Kampmiller, T. \& Vanderka, M. (2006). Oneskorená svalová citlivost „svalová horúčka“ v kondičnej príprave športovcov. Atletika, pp.84-88.

5. Morgan, D.W., Martin, P.E. \& Krahenbuhl, G.S. (1989). Factors affecting running economy. Sports Med, 7, pp.310-330.

6. Spurrs, R.W., Mureny, A.J. \& Watsford, M.L. (2003). The effect of plyometric training on distance running performance. Eur J Appl Physiol, 89, pp.1-7.

7. Støren, Ø., Helgerud, J., Støa, E.M. \& Hoff, J. (2008). Maximal strength training improves running economy in distance runners. Med. Sci. Sports Exerc, 40, pp.1087-1092.

8. Turner, A.M., Owings, M., Schwane, J.A. (2003). Improvement in running economy after 6 weeks of plyometric training. J Strength Cond Res, 17, pp.60-67. 